\title{
THE EFFECT OF USING CONTEXTUAL REDEFINITION STRATEGY ON STUDENTS' READING NARRATIVE TEXT OF ELEVENTH GRADE AT SMA N 8 MEDAN
}

\author{
Yohana M Simanjuntak \\ English Department of FKIP in University of HKBP Nommensen, \\ Email:yohanasimanjuntak755@gmail.com
}

\begin{abstract}
This study aimed to see the result of students's achievement in reading narrative text with applying Contextual Redefinition Strategy. The population of the study was the elevent grade students of SMA N 8 Medan on 2019/2020 with the total number is 180 students. Two classes were taken as the sample they were IX IPA 4 and IX IPA 5. The experimental group was taught by using Contextual Redefinition while the control group (IX IPA 5) was taught by using conventional method. The instrument of collecting data was multiple choice test. The data were analyzed by using t-test. Based on the data, it was found that the students' score improved from pre-test and post-test in experimental class. The result shoe that t-observed is higher that t-table value $(2.9>1.671)$ at the level significance 0,05 and the degree of freedom is 58 . Therefore, it can be concluded that the null hypothesis (Ho) is rejected and alternative hypothesis (Ha) ia accepted. Based on the research result, there is a significant effect of using Contextual redefinition strategy in eading Narrative test of Eleventh Grade Students' at SMA N 8 Medan.
\end{abstract}

Keywords: Contextual Redefiniton, Reading Narrative Text

\section{Introduction}

Language is a human system of communication that uses arbitrary signals, such a voice sounds, gesture, and/or written symbols. Language is a tool of communication that using by the society in the life because with the language people can create their ideas, emotions and desiers by means of voluntarily produced symbols.In this case, this fucntionhas a role to share information for students to understand about all of the events in the world wide, because in this world many people use english language. In Indonesia English has an important role especially in Education. Therefore, English is as the first foreign language in all levels of schools and language courses. English is the largest language used people to communicate globally in the world. By using English, people exchange information that would be spoken and written. In Indonesian, English is an important foreign language which is taugh from elementary school level up to university, because in Indonesian many school to learn english, so that the students in everyday using the english to communicate and to search information.
English has four basic skills that must be mastered by teachers and learners. They are Reading, Writting, Speaking, Listening. One of that is Reading. Reading is one of the skill in teaching English that have to mastered by the teachers or the students to achive learning process. It has always occupied place in most English language course.

Reading is one of four English skills that have to mastered by all of the English learners. Readig is a language skill that needs reader to comprehend a text. In addition, reading is the ability to receive information, to get pleasure, to get main idea so, everybody can improve his or her knowledge.

The aim of reading activity is to getting good comprehension, if the reader can not comprehend the text so that they can not get the information and the knowledge. Reading comprehension is an interactive process. In other word, when reading activity the students have to find the meaning of the text, because if the students do not understand the text, it means that they have no interaction with the teacher. In addition, Guthrie et al (2004:193) state that reading comprehension consist of the processes constructing conceptual knowledge from a text through cognitive 
interaction and motivational involvement with the text.Mark Sadoski (2004:18) explain that the aim of teaching reading is to anable the studentscomprehend and react to is written. There are so many Genre in Reading text such as narrative, recount, descriptive, report etc. In this research, the writter focusses on narrative text. According to Sipayung and Tagor Pangaribuan (2018)Teaching is a teacher's enterprise. He is doing it in classroom. In a simple synoptic, a teacher is greeting students, explaining the matter, ask learners participants and $\mathrm{o}$ the homework. This has been the teaching trade, and a tradition.

In teaching reading there were so many strategies that can help the students such as: Pyramid Diagram strategy, Anticipate Guide strategy, Think Aloud strategy, REAP strategy and Contextual Redefinition strategy etc. Therefore, the writter choose one strategy that made the students more interest in reading learning process namely Contextual Redefinition strategy. It needs a suitable strategy to enhance students' reading on narrative text. Bras sel (2011:26) state, "Contexttual Redefinition Strategy is an instructional strategy that through structural analysis of the words to associate with other meaningful word parts to help them inconstructing the meaning of the word and understanding the text".

Based on my experience when the writer was teaching traning practice in SMA $\mathrm{N} 8$ Medan, the writer was very difficult to comprehend English text. The students were difficultty comprehend the main idea of the reading text, some of the students were not able to identify the generic structure and language feature of narrative text. And some of them were not interested in reading narrative text. The strategy used by the English teacher in this school was Comprehension-Based Approach. The strategy used by the teacher made the students bored and some of them were not interested in reading. As a result they still got low score in reading. Based on explanation above, some of the students still face various problems and difficulties in English, especially in reading narrative text. So the contextual redefinit ioncan be alternative strategy that can accomodate the problem and practical solutions in reading narrative text. The students were not able to understanding about narrative text. Especially about generic structure of narrative text that consisted of orientation, evaluation, compilication, resolution, re-orientation. The writer checked students' answer sheet based on scoring the test. There were: orientation (20), evaluation (20), complication (20), resolution (20), reorientation (20).

Table 1

The Table of Rubic Score

\begin{tabular}{|c|c|c|c|c|c|c|c|}
\hline \multirow{2}{*}{$\begin{array}{l}\mathbf{N} \\
\mathbf{0}\end{array}$} & \multirow{2}{*}{$\begin{array}{c}\text { Stu } \\
\text { den } \\
\text { ts' } \\
\text { Init } \\
\text { ial }\end{array}$} & \multicolumn{5}{|c|}{ Components of Reading Narrative } & \multirow{2}{*}{$\begin{array}{l}\text { Total } \\
\text { score }\end{array}$} \\
\hline & & $\begin{array}{c}\text { Orie } \\
\text { ntati } \\
\text { on }\end{array}$ & $\begin{array}{c}\text { Eval } \\
\text { uatio } \\
\mathbf{n}\end{array}$ & $\begin{array}{c}\text { Com } \\
\text { plica } \\
\text { tion }\end{array}$ & $\begin{array}{c}\text { resol } \\
\text { utio } \\
\mathbf{n}\end{array}$ & $\begin{array}{c}\text { Re- } \\
\text { Orie } \\
\text { ntati } \\
\text { on }\end{array}$ & \\
\hline 1 & $\mathrm{DM}$ & 8 & 8 & 12 & 4 & 0 & 32 \\
\hline 2 & SR & 4 & 4 & 8 & 4 & 4 & 24 \\
\hline 3 & $\mathrm{RP}$ & 8 & 12 & 4 & 4 & 12 & 40 \\
\hline 4 & AL & 8 & 12 & 4 & 4 & 12 & 40 \\
\hline 5 & PP & 12 & 12 & 16 & 16 & 16 & 72 \\
\hline 6 & WR & 12 & 12 & 8 & 4 & 12 & 48 \\
\hline 7 & GP & 16 & 16 & 12 & 12 & 16 & 72 \\
\hline 8 & LP & 16 & 16 & 4 & 4 & 12 & 72 \\
\hline 9 & $\mathrm{SN}$ & 8 & 12 & 4 & 4 & 12 & 40 \\
\hline 10 & $\mathrm{RM}$ & 12 & 4 & 12 & 4 & 8 & 40 \\
\hline 11 & SA & 12 & 4 & 12 & 4 & 8 & 40 \\
\hline 12 & MA & 20 & 12 & 8 & 12 & 0 & 32 \\
\hline 13 & $\mathrm{CR}$ & 12 & 12 & 8 & 12 & 8 & 52 \\
\hline 14 & $\mathrm{DM}$ & 12 & 12 & 8 & 12 & 8 & 52 \\
\hline 15 & $\mathrm{ZS}$ & 12 & 12 & 16 & 12 & 8 & 60 \\
\hline 16 & NP & 12 & 16 & 16 & 16 & 16 & 76 \\
\hline 17 & BL & 12 & 12 & 16 & 12 & 8 & 60 \\
\hline 18 & AS & 8 & 12 & 4 & 4 & 12 & 40 \\
\hline 19 & $\mathrm{KN}$ & 8 & 12 & 8 & 12 & 12 & 52 \\
\hline 20 & FH & 4 & 4 & 12 & 12 & 12 & 44 \\
\hline 21 & US & 4 & 12 & 12 & 8 & 12 & 48 \\
\hline 22 & DI & 8 & 12 & 8 & 12 & 12 & 52 \\
\hline 23 & BP & 8 & 8 & 12 & 12 & 12 & 52 \\
\hline 24 & HS & 12 & 12 & 8 & 4 & 12 & 48 \\
\hline 25 & CL & 8 & 8 & 12 & 4 & 8 & 40 \\
\hline 26 & BS & 8 & 4 & 8 & 12 & 0 & 32 \\
\hline 27 & LK & 8 & 4 & 8 & 12 & 0 & 32 \\
\hline 28 & $\mathrm{AB}$ & 12 & 12 & 16 & 12 & 8 & 60 \\
\hline 29 & EL & 8 & 20 & 16 & 16 & 12 & 72 \\
\hline 30 & $\mathrm{PO}$ & 4 & 4 & 8 & 8 & 8 & 32 \\
\hline \multicolumn{7}{|c|}{ Total } & 1456 \\
\hline & & & & Mean & & & 48,53 \\
\hline
\end{tabular}

Based on the data above the eleventh grade students of SMA N 8 Medan got early 48,53 for the mean score for reading. It can be concluded that they have some problem in reading, they were lack in reading.

Contextual redefinition strategy has the adventages to help studentsfocuss on the most important part of the text, a necessary skill for comprehension. Thus, it can help students comprehend a text event though there are many unfamiliar words or seem in the text. Finally, the writer would be conducted a research entitled: The effect of using contextual redefinition strategy in reading narrative text of eleventh grade students at SMA N 8 Medan. 
Reading is one of the skills that will be mastered by the students. It is an important subject in teaching and learning process. So, if the readers want to know that meaning words of text, they have to be able to understand the words and also comprehend what they have read. Harmer (2007: 99) state" reading is useful for language acquisition. Provided that students more or less understand what they read, the more they read, the better they get at it." If students want to be successfull in the schools the must be able to remember and understand what they read.

Strategy is needed in teaching english. By implementing strategies, the students can understandthe topic that teacher explain easily. B rown (2007:119) state strategies are spesific methods of approching a problem or task,modes of operation for achieving a particular end, planned designed or controlling and manipulating certain information.

Brassel (2011:26) stated, contextual redefinition strategy is an instructional strategy that do through structural analysis of the words to associate with other meaningful word parts. This offrs studnts specific steps for deducing the meaning of unkown (or uclear) words in reading passage. Contextual Redefinition strategy has the adantages to help students focuss on the most impotan part of the text, a necessary skill for comprehension.

O'Malley in Brown $(1994 ; 117)$ defined that contextualization is placing a meaning of word in language progression. O'Malley stated that contextual redefinition strategy offers students specific steps for deducing the meaning of unknown (unclear) words in a reading passage by seeking clues from their context in a larger text selection. This strategy encourages students to focus on what is clear and obvious in a reading selection, to state, as much as is possible, the author's general intent or meaning in a passage, and to use these observations to help interpret unclear terms and ideas within the known context. Otherwise, contextual redefinition strategy calls for close attention to word order, syntax, parallel ideas, and examples as keys for predicting word meaning (Nation, 2001).

Brassel, (2010:26) stated the purpose of the strategy follows:

a. To demostrate the students the importance of using all contextual clues available to determine the meaning of unfamiliar words. It means that using context clues will make the students easy to guess the meaning of the difficult words.

b. To show the students how to mak educated guesses about the meanings of unfamiliar words utilizing context. It means that this strategy will give a new a way to know the meaning with guess the meaning of the difficult words.

c. To make students active partcipations in the discovery of new words. This strategy will make the students active because in the steps of this strategy the students can explor their idea or they can guess the meaning with their knowledge.

d. To allow the students to share their trought process with one another and understand different ways to device meaning from the text. It means that every student has the different consideration about the word that they guess. And they will seek the meaing of the difficult word together.

From the explanation above, the writer conclude that the contextual redefinition is very helpful in teaching reading, because there are many benefits in using this strategy. The contextual redefinition also can activate the students prior knowledge.

Readance, Bean, \& Baldwin,(1998:27) stated the procedures of Contextual Redefinition strategy consist of:

1. Select unfamiliar vocabulary words from the reading.

2. Write a sentence that includes each word. The sentence should give clues to the meaning of the vocabulary word.

3. Divide sudents into small groups.

4. Present individual words to groups students. This can be done with a whiteboard or transparency, using powerpoint, or on paper. In some cases, it may help to pronounce each word for the students.

5. Instruct students to define each word based upon background knowledge, and to be prepared to explain why the definition is correct.

6. After students have finished providing their own definitions, gives each group vacabulary words in the context of how they appear in the reading.

7. If necessary, ask students to use the sentence to modify previous definitions.

8. After modifications are made, direct students to verify definition using the glossary or dictionary. 
Contextual redefinition strategy has advantages to help students focus on the most important part of the text, a necessary skill or comprehension. According to Readance, Bean, \& Baldwin, (1998:27) the Benefit of Contextual Redefinition strategy consist of:

1. Provides a structure for teaching students how to use context clues to decode and understand challenging text

2. Provides teacher flexibelity and opportunity to differentiate instruction depending uon the words given to each group

3. Facilitates a deeper understanding of the text

4. Actively engages students in the process of deliberation

5. Encouranges student collaboration

6. Prepares students for independent reading

7. Provides a framework for a civil and respectful discussion

8. Moderate aadvance preparation requred by the teacher.

In this study, the instrument for collecting the data were useda reading test. The writer would be given the multiple-choice tests from Narrative text. Each of the test consists of four options namely A,B,C, and D. The tests consits of 25 items in the form multiple choice questions, and each item weregiven score 4 . The students were given a test to measure students in reading divided into two stages. The first is pretest, it will be given before the treatment. The second is post-test, it was given after the treatment. Accroding to J. Charles Alderson (1995:211) "multiple choice questions are a comment device to testing students' comprehension". The test were used to know the score of students' in reading narrative text. There are some consideration why the writer use the multiple choice. First, it is effective to measure. Second, it is objective scoring which is practical and consitstent. Third, it consists of a relative large number of question which is needed. lastly, usually encouraged students to develop a comprehensive knowledge of practicular test.

\section{Findings}

The data obtain from the score of the experimental and control group. The students who are taught by implementing Contextual redefinition Strategy got significantly improvement in reading narrative text while, there is no significant improvement for control group who is taught without Contextual Redefinition strategy. It can be seen from mean score of pos-test in experimental group is 70.6 is higher than the mean score of post test in control group is 53.4 Then, the calculation result of the t-test in data analysis above, the hypothesis is proved that the value of t-observed is higher than t-table, the are 2.9> 1.671 at the level of significance alpha 0.05 and the degree of freedom $(\mathrm{df})=58$. Therefore, Contextual Redefinition Strategy significantly affects in reading narrative text of eleventh grade students at SMA N 8 Medan.

\section{Discussion}

As explain in the literature review, there are four language skils, namely listening, writing, reading, speaking. Reading is a fluent process of readers combining information from a text and their own background knowledge to build meaning. Reading is the practice of using text to create meaning. The two key words here are creating and meaning. If there is no meaning being created, there is no reading taking place.It means that reading with comprehension means understanding what has been read. Most of students have minimum willing in reading. The students could read English word and sentences in text, but they just read it without trying to understand the content of the text they have read. The students seen unable to interprate the text accurately. When the teacher asked a students to read text, another students would make a noise i their seat without listening to their friend. That is the students' problem in the process of reading.

To solve the students' problem in process of reading, the teacher can implementing Contextual Redefinition Strategy as an alternative strategy inteaching reading narrative text would improved because Contextual Redefinition strategy over a new way to develop student's achievement in reading. Fastrup and Samuel (2008:56) stated, Contextual Redefinition Strategy encourages students to concentrate on what is clear in reading passage, state the meaning as much as possible, and use the context to interpret unclear terms. Thus, it can help students comprehend a text even though there are many unfamiliar words or terms that contain in thetext. Readance, Bean, \& Baldwin (1998:26) stated Contextual Redefinition stategy is to assist students with contextual analysis by helping them make educated guesses related to the meaning of a specific word In this case, Contextual Redefinition is a very useful and effective strategy for the students in reading narrative text because students will be better prepared to read efficiently and proficiently 
about text. This strategy can be applied in some types of the text such as fiction and nonfiction. Besides that, Contextual Redefinition strategycan be easily modified for most contents areas. The question in this strategy should follow the levels of bloom taxonomy.

\section{References}

Brassel, Danny. (2011). Comprehension that works. United of America: Sheel Education

Brennan, R. (2001). Generalizability Theory, New York, USA: Springer-Verlag.

Brown, H. Douglas. (2001). Teaching by Prnciple An Interacctive Technique to Language Pedagogy. San Fransisco: Longman.

Brown, H. Douglas. (2007). Principle of Language Learning and Teaching. U.S.A: Pearson Education, Inc.

Burns, et al (1984). Collaboration action research for reading Comprehension. Cambridge: Cambridge University Press.

Charles, J. Alderson. (1995). Multiple Choices Test Construction and Evaluation. Cambridge University Press.

Cunningham, J. W, P. M. Cunningham, and S. V. Arthur. (1981). Middle and Secondary School Reading. New York: Longman.

Derewinka, B. (1991). Exploring how text work. Sydney: Primary English Teaching Association (PETA).

Furchan. A. (2004). Pengantar Peneliti dalam Pendidikan. Yogyakarta: Pustaka Pelajar.

Gay, L. R. (2000). Educational Research: Competencies for Analysis and Application Sixth Edition, New Jersey: Prentice Hall Inc.

Gerot, Linda and Wignell, Peter. (1995). Making Sense of Functional Grammar, Sydney: Tanta Stabler.

Grabe, W and Frederica L. Stoller. (2002). Teaching and Researching Reading. England: Pearson Education Limited.

Guthrie. (2004). Comprehension that Works: Taking Students Beyond Ordinary Understanding to Deep Comprehension. Huntington Beach: shell Education.

Harmer, J. (2001). How to Teach English. New York: Longman Press.

Herber, H. (1992). Teaching Readng in Content Areas. 2nd ed. Englewood Cliffs, J: PrenticeHall.

Johnson, K. (2008). Teaching Reading Vocabulary. New York: Pearson Limited.

Kane, Thomas. S. (2000).The oxford Essential Guide to Writting. New York: Barkley Books.

Klinger, et al, (2007). Teaching Reading Comprehension With Learning Difficulties, New York: The Guildford Press.

Kustaryo, S. (1998). Reading Technique for College Students. Jakarta: Departemen Pendidikan Kebudayaan.
Maya, R. (2001). Thesis: Improving Student Reading Comprehension through REAP strategy. Medan.

Moreilon, Judi. (2007). Collaborative strategies for teachin reading comprehension: Maximizing Your Impact. Chicago: American Library Association.

Pardiyono. (2005). Teaching Genre Based Writting. Yogyakarta: Penerbit Andi.

Patel, M.F. \& Jain, Praveen M. (2008). English Language Teaching (method, tools \& Techniques). Jaipur: Sunrice Publishers.

Popham, W. (1995). Classroom Assesment What Teacher Need to Know. Boston: Simon \& Schuster Company.

Readence. J. E, Bean, T. W., \& Baldwin, R. S. (1998). Content Area Reading: An Integrated Approach (6th ed). Dubuque, IA: Kendall/Hunt.

Richards, J. \& Rodgers, T. (2001). The Nature and Methods in Language Teaching. Cambridge: CUP. Fifteenth Printing.

Rosyada D. (2008). Media Pembelajaran. Jakarta. Gaung Persada.

Sadoski, Mark, (2004). Conceptual Foundations of Teaching Reading, New York: The Guildford Press.

Siahaan, S. \& Shinoda, K. (2008). Ggeneric Text Structure. Yogyakarta: Graha Ilmu.

Solon, C. (1980). Journal Reading "The Pyramid Diagram: A college Study Skills" Tool.

Sugiyono. (1997). Metodologi Penelitian Administrasi. Yogyakarta: CV Alfabeta.

Sugiyono. (2010). Reseach Method Quantitative. Bandung: Alfabeta.

Syafi'i, M. S, (2007). From Paragraph to a Research Report; A Writing of English for Academic Purpose, Pekanbaru: Lembaga Bimbingan Belajar Syaf Intensive/ LBSI.

Tierney, Robert J. at all. 2009 Reading Strategies and Practice. A Compendium. Third Edition. Allyn and Bacon USA..

Tagor Pangaribuan, KT Sipayung. (2018). "Thomas Hardy: A Better Understanding of his Claimed Pessimism, its Causes and Influence". International Journal on Studies in English Language and Literature (IJSELL), vol 6, no. 7, 2018,pp.6-1 
